\title{
DEVERBAL -MINE ACTION NOMINALS IN THE ESTONIAN DIALECT CORPUS
}

\author{
Maarja-Liisa Pilvik \\ University of Tartu
}

\begin{abstract}
This article describes the typical properties and functions of Estonian -mine action nominals, using dialect corpus data. The dialect data entails non-standard spoken language with a regional dimension and therefore has the potential to display more variation in terms of the behaviour of action nominals in actual language use. This will be demonstrated, inter alia, by the non-canonical realization of arguments, e.g. retaining the sentential form of the patient argument, in phrases headed by -mine action nominals. The article also discusses the problems of assigning a word class to the regularly derived and productive type of action nominals, when taking into account all the possible contexts and constructions in which they can occur.
\end{abstract}

Keywords: dialect syntax, action nominals, nominalization, constructions, Estonian

DOI: https://doi.org/10.12697/jeful.2017.8.2.10

\section{Introduction}

In Estonian, the most general, productive and regular means for nominalizing a verb is adding the deverbal suffix -mine (morphological variants of which are common to all Finnic languages) to the corresponding verb stem (e.g. laulma 'to sing', laulmine 'singing'). The results of the nominalization, referred to as action nominals in this article, are traditionally considered to belong to the noun word class (Erelt et al. 1995, Erelt et al. 1993, Kasik 2015, Erelt 2014: 236) and semantically represent a concept instead of a process, or in other words, an entitized referent instead of a situational one, thereby constituting a mechanism for syntactic and conceptual reformulation. It is evident, however, that based on the contexts in which -mine action nominals (from here on abbreviated as mine-ANs) appear, they cannot be described solely based on their traditional part of speech properties and instead lie somewhere in between word classes, exhibiting both verbal and nominal features and participating in constructions with their own 
semantic and syntactic characteristics (cf. Neetar 1988, Sahkai 2011, Pilvik 2016). The present article uses Estonian dialect corpus ${ }^{1}$ data to give an overview of the typical syntactic environments of mine-ANs and highlight the more noun- or verblike properties associated with their uses in particular contexts.

Nominalization is a transpositional (i.e. word-class-changing) derivation phenomenon, through which a base lexeme of some word class is turned into a noun (Haspelmath and Sims 2010: 253-255, Koptjevskaja-Tamm 2006: 652). In describing mine-ANs in this article, I am placing the focus on the result of deverbal action nominalization, i.e. on nominal structures which incorporate a reclassified verbal component and denote the event or action itself, not a participant in that event. Despite what the term action nominal may imply, the resulting nouns refer to situations in general (i.e. processes and states), not only strictly actions (Koptjevskaja-Tamm 1993, Koptjevskaja-Tamm 2006).

-mine nominalization is morphologically a derivationa ${ }^{2}$ process, the result of which is a noun (or a noun phrase) and can therefore be inflected for categories such as number and case (e.g. laul-mis-te-st singAN-PL-ELA 'of the singings'). Syntactically, it is a secondary means for expressing predication, meaning the resulting action nominal construction is not a sentence due to formal and functional incompleteness, but is similar to a sentence in some syntactic respects, i.e. in being able to preserve the verb's valence. The results of (predicate) nominalization in Estonian therefore fall into the same functional category as non-finite verb forms, such as infinitives, converbs and participles. (Erelt et al. 1993: 232-233, Ylikoski 2003, Erelt 2014) A situation denoted by a verb and its arguments is modified to serve as an argument or a modifier of another verb. The action nominal therefore inherits the base verb's valence and usually expresses the verb's arguments corresponding to the subject or object in the form of prenominal genitive modifiers. It is not common cross-linguistically, however, for action nominals to occur with the full set of the verb's arguments in actual language use, but instead only one argument at most is chosen to receive overt expression

1 The Corpus of Estonian Dialects is available online at $<$ http://www.murre.ut.ee/mkweb $>$.

2 Classifying productive and regular action nominalization as a derivational process or an inflectional phenomenon is somewhat debatable for many languages (see e.g. Koptjevskaja-Tamm 1993: 263-266, Ylikoski 2003: 188, Haspelmath and Sims 2010: 98-105), and might pose problems in lexicology and theoretical linguistics. However, for the purpose of this article, which is essentially descriptive and focuses more on the semantics and morphosyntactic behaviour of action nominals, the labeling is of little relevance. 
(Hopper and Thompson 1984: 738). This has also been referred to as the reduction of actual valency (Mackenzie 1985), i.e. the actual occurrence of arguments in noun phrases headed by action nominals in actual language use. For Estonian, several aspects, such as animacy of the arguments, the degree of processuality in the action nominal, and conventions, may influence the choice of explicit argument marking in action nominal phrases (e.g. Kasik 1968).

mine-ANs in written Estonian have been exhaustively described, and although there are some important works on action nominals also from a constructionalist perspective (Sahkai 2005, 2006, 2009, 2011, Muischnek and Sahkai 2010), the main focus has been on action nominals from a morphological-derivational point of view (Kasik 1968, 1975, 2004, 2015) or as a complex lexical characteristic of certain genres of written language (Kasik 2006a, 2006b, Kerge 2001, 2003), where mineANs are used for generalizations and abstractions (compared to subordinate clauses), for "thickening" the text, or for creating terminology. Also cross-linguistically, nominalization and action nominals, in particular, have been investigated mainly from the perspective of word formation, word classes and the relation of the nominalized phrases to subordinate clauses, with a clear focus on the internal structure of the nominalized NPs (Koptjevskaja-Tamm 1993, Malchukov 2004, 2006, Comrie and Thompson 2007, among others). In the languages of the world, however, nominalization has an important role in a much wider variety of grammatical domains, serving various morpho-syntactic, semantic, pragmatic, and discursive functions (e.g. Noonan 1997, Yap et al. 2011), and action nominals are a central part of various constructions conveying their own idiosyncratic meaning. A terminological remark at this point is relevant. In this article, the term action nominal constructions is not reserved to denote only nominalized NPs with action nominals as their heads (e.g. vaenlase hävitamine 'the destruction of the enemy'), as e.g. Comrie (1976) and Koptjevskaja-Tamm $(1993,2006)$ define it, but is referring to a heterogenous class of more or less schematic linguistic units, in which action nominals occur and which do not have a strictly compositional meaning. Also, as the terminology concerning the result of nominalization in linguistic contexts is far from clear, the term action nominal is preferred over other possible denominators such as gerund, masdar (Haspelmath 1993, 1995), event/action noun (Haspelmath and Sims 2010) etc. The term nominalization is reserved for a wider set of processes used to convert some lexeme to a noun.

The aim of the current article is to highlight the nominal and verbal properties of Estonian mine-ANs from morphosyntactic, semantic and 
discourse-related perspectives, and describe the syntactic environments in which they occur as well as the realization and form of their arguments in the corpus of Estonian dialects. Although mine-ANs have been mainly considered a characteristic of written Estonian (Kasik 2006a, 2006b, Kerge 2003) and their frequency in spoken data has been found to be considerably lower (Uiboaed et al. 2013), spoken dialect data is chosen first and foremost due to its potential to exhibit more variation in terms of argument realization and different constructions than standard written Estonian. Dialect data is also more appropriate when trying to find the counterparts of different constructions in other Finnic languages, many of which have a very short written language tradition or do not have one at all. The article also aims to contribute to the hitherto little researched field of Estonian dialect syntax more generally. The description is usage-based in the sense that it outlines the typical functions of mine-ANs present in the corpus data (i.e. in spoken dialect interviews) and therefore relies on data from actual language use, while it does not represent an exhaustive description of deverbal mine-nominalization as a process.

The data the current article comes mostly from the morphologically annotated part of the Corpus of Estonian Dialects, which consists of transcripts of semi-structured interviews recorded mainly during the 1960s and 1970s. The data in the corpus represents 10 traditional dialect areas: Insular, Western, Mid, Coastal, Northeastern, and Eastern, making up the northern dialects, and Mulgi, Tartu, Võru, and Seto, forming the southern dialect group. At the time of data collection, the corpus consisted of 956007 running words, from which a dataset of 1928 observations of mine-ANs was automatically extracted and manually checked. While it is difficult to make assumptions about the diachronic and functional development of mine-ANs, since the dialect corpus represents texts from only a relatively short period of time, we can observe the behaviour of the action nominals synchronically in traditional dialects still spoken at least at the time of their recording. As the dialect corpus with its less than a million morphologically annotated tokens is rather small, the amount of data from different dialects is highly unbalanced, and mine-ANs are distributed over a wide range of functions, no inferences will be made regarding differences between dialects in terms of the behaviour of -mine nouns. For the same reason, I will also refrain from reporting frequencies of occurrence in this article. The article will be mainly descriptive and schematic, aiming at giving a maximally broad overview of the phenomenon. 


\section{Nominal and verbal properties of mine-ANs}

There is a clearly motivated temptation to investigate the nominal and verbal properties of mine-ANs and perhaps to look for evidence for distinguishing between the more nominal and the more verbal properties of action nominals and even argue for their reclassification. Firstly, they are in many respects similar to both nouns and non-finite verb forms and because of that have, at different times, been considered to belong to both categories. Secondly, similar dichotomous distinctions of analogous phenomena have received general acceptance in the descriptions of other languages. For example, in English, a distinction is made between nominal and verbal -ing gerunds, the latter of which have developed from the former starting from Early Middle English. Nominal gerunds are said to function as all other nouns, meaning that they could also take dependents mostly occuring with nouns, such as determiners, genitive phrases or adjectives. Verbal gerunds, in turn, are able to govern an object or a predicative complement, can be modified by adverbs and adverbials that otherwise only occur with verbs, can be negated with not, show tense and voice distinctions, and take a subject in a non-genitive case. (Fanego 2004) The distinction is connected to the cross-linguistically attested continuum between action nominals and nominalized clauses (De Smet 2008: 55).

mine-ANs lie in between prototypical nouns and verbs in terms of their morphological, syntactic and semantic behaviour. Although in the process of nominalization in Estonian, verbal categories such as voice, tense, mood, and person are lost, while nominal categories such as case and number are acquired (naturally indicating the nominal nature of mine-ANs in terms of word classes), several properties, for example, allowing adverbial modifiers or even the realization of the verb's arguments in some contexts point to action nominals' preserving the original sentential properties. Haspelmath and Sims (2010) have suggested describing transpositional categories with ambivalent behaviour similar to that of mine-ANs, such as participles, masdars and proprietives, through dual word class membership, distinguishing between a word's word-form word class (responsible for the external syntax of that word, i.e. the functions of the action nominal phrases in sentences) and lexeme word-class (responsible for the internal syntax of that word, i.e. the relation between the head and dependents). Although it would be simple to conclude that both the word-form word class and the lexeme word class indicate the nouny nature of mine-ANs (they mostly take on the same 
roles as all other nouns in a sentence and their complements are also often marked the same way), there is still some ambiguity and variation in both respects in the behaviour of mine-ANs, as I will show. Others (e.g. Vare 1991) have taken an even broader perspective and called the conflict between word classes a pseudo-problem as word class is only a secondary feature of a situational relationship, the expression of which is not a sole privilege of verbs and which is only realized in a specific syntactic context. This argumentation is indeed in line with the notion of transpositional derivation, which changes a word class for syntactic reasons without changing the meaning of the situational relationship (Kasik 2015: 33-34). Vare (1991), however, also adds, that as many linguistic expressions have the ability to express a situational relationship in certain semantic-syntactic environments, those expressions should not be hierarchically related by stating that one word class is derived from another or that some inflections are founded on admittedly arbitrary "base forms" of the lexicon. All this implies that reporting the mere loss or acquisition of certain morphosyntactic categories might not be sufficient for accurate descriptions of action nominals and a more fine-grained analysis including descriptions of the contexts in which action nominals appear in actual language use and the functions the nominalized structures hold in these contexts might be beneficial for a deeper understanding of the phenomenon at hand.

In the present article, I analyze mine-ANs mainly based on the distinction between features prototypically related to either the nominal or the verbal domain. In addition, I will describe the semantically and functionally idiosyncratic constructions in which mine-ANs are an obligatory component of or in alternation with other non-finite verb forms. It is important to stress, however, that I will not make any implications on the necessity of recategorization of action nominals in grammatical descriptions of Estonian or other Finnic languages, but rather seek to illustrate the inter- and transcategorial nature of the phenomenon using non-standard spoken language data.

\section{1. mine-ANs as typical nouns}

mine-ANs, like other non-finite constructions, are syntactically nominal constituents and thus belong to the sentence as its immediate constituents or as attributes in an NP (Erelt et al. 1993: 232). The inflectional morphology and a large part of both the external and internal syntax of the nominalized phrases reflect the prototypically nouny 
nature of mine-ANs. First and foremost, action nominals have a full case paradigm. Like typical Estonian nouns, mine-ANs decline in all 14 cases and can therefore occur in any syntactic position except for the predicate. The frequency of case forms in actual language use is obviously different for different cases. In the Estonian dialect corpus, by far the most frequent case for mine-ANs is the nominative, followed by the genitive and partitive ${ }^{3}$. As for all nouns, the grammatical cases identify nominal syntactic roles corresponding to the predicate's arguments, i.e. subjects (1) and objects (2) of normal clauses, but also both participants of predicative expressions $(3,4)$; they are typical cases for complements in adpositional phrases $(5,6)$, and genitive is the canonical case also for attributes (7), where action nominals usually express purpose. ${ }^{4}$
(1) $\left[*^{*}\right.$ neije
*rääkki-mine]
*kuulu-s
*ranna-le (COASTAL)
they.GEN
speak-AN.NOM
sound-IPF.3SG
coast-ALL
'Their speaking could be heard to the coast.'

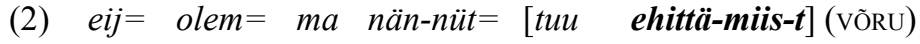
NEG be.CNG I see-APP it.GEN build-AN-PART

'I haven't seen its construction.'

(3) selle+bärast ei ole-gi [see väga suur 'eit-mine $]$ because_of_that NEG be.CNG-CLI this very big swarm-AN.NOM

ei ole ea (WESTERN)

NEG be.CNG good

'This is why very big bee swarming is not good.'

(4) sie $\quad n o h=o l-i \quad[$ pattu $=$ tege-mine $] \quad$ võ

this PAR be-IPF.3SG sin.GEN commit-AN.NOM or

'seokkõ (INSULAR)

like_that

'Well, this was committing a sin or something like that.'

3 This case distribution can not be attributed only to dialect data, as the same tendency can be observed for different genres of written language based on the frequency lists of parts-of-speech and grammatical categories of nominals based on the Balanced Corpus of Estonian (http://www.cl.ut.ee/ressursid/gram-kat/tabe19,10,11,12,13/).

4 The examples are in the simplified transcription of the dialect corpus. ' and * designate the 3 rd degree of quantity, (.) and (...) mark pauses, = stands for coarticulation, + is used in compounds, and ' indicates palatalization of the previous consonant. 
(5) mina sa-i-n piibli raamadu [[oma luge-mise $]$ I get-IPF-1SG bible.GEN book.GEN own.GEN read-AN

eest ['leeri-s]] (INSULAR)

POSTP confirmation-INE

'I got a bible for my reading in the confirmation class.'

(6) ja mõn'i nuhh mõn'i tul'l' viil (.) [perähh and some PAR some come.IPF.3SG PAR PREP 'ris't-mis-t] kaa (VÕRU) christen-AN-PART too

'And well, some came also after the christening.'

(7) eks täma-l ôl-d [[põdra = 'lask-mise $]$ õigus $]$ (NORTHEASTERN) PAR he-ADE be-APP moose.GEN shoot-AN.GEN right

'Well, he had the right to shoot moose.'

mine-ANs in the remaining semantic cases function as various adverbials, expressing e.g. location (8) or oblique arguments (9), and are likely to be used similarly to converb constructions (see next section). mine-ANs in the illative, ablative, essive, terminative, and abessive are not present in the dialect corpus data, which is possibly an indication of the relatively peripheral use of these cases in actual language use, compared to other cases, but can also speak of the action nominals' unprototypicality in the functions tied to these cases.

(8) ning kõik vii-d-i ikka ‘uuri-mise-le ikka

and everyone take-IPS-IPF PAR investigate-AN-ALL PAR

kess ‘ikka sääl vastu+'akkaea-tte poolt ol-i (INSULAR)

who PAR there rebel-PL.GEN POSTP be-IPF.3SG

'And everyone who was on the rebels' side was taken to the investigation [office].'

(9) no muu-d maa $=i \quad$ tiijäq nii (.)

PAR other-PART I NEG know.CNG PAR

[tuu-st 'kaehta-mise-st $]$ selettä-q (...) (VÕRU)

that-ELA bewitch-AN-ELA tell-1INF

'Well, I don't know what else to tell you about the bewitching.' 
In the grammatical descriptions of some cognate languages (e.g. Finnish, Livonian), a distinction is made between regularly derived action nominals, which have a full case paradigm and can take any noun modifiers, and deverbal nouns (or infinitives) participating in certain syntactic functions (e.g. necessive constructions), where the morphosyntactic behaviour of the deverbals is restricted to only certain specific inflections and combinations (for Finnish, e.g. Hakulinen et al. 2004, for eastern Livonian, Viitso 2014: 208 footnote). This distinction, at first, seems to be motivated mainly by the desire to compromise in the admittedly difficult task of classifying the versatile and ambivalent nature of action nominals and non-finite verb forms in language descriptions (Vare 1991: 409-410). The distinction is also valid for morphosyntactic and semantic reasons, however (see next section). The fact that a lexeme which can have a full set of forms clearly cannot function in every syntactic context in the same form does not necessarily call for postulating different action nominals with the same suffix, but there is certainly a need for descriptions of the behaviour of action nominals in different syntactic environments.

mine-ANs, like most nouns, can be pluralized, although pluralization of action nominals is relatively rare in the dialect corpus. According to Kasik (Kasik 2004: 91), only mine-ANs in the singular can be used for denoting a process. In the light of examples 10 and 11, which still seem to refer to processes, this statement alone is insufficient to explain the difference between singular and plural uses of -mine nouns.

$\begin{array}{lllll}\text { (10) siäl oli-d jälle (.) } & \text { keet-mise-d ega }= \\ \text { there } & \text { be-IPF.3PL PAR } & \text { cook-AN-PL.NOM NEG }\end{array}$

'The cookings all happened there, back then you didn't have anywhere to cook.'

(11) timä ol'l'(.) ol'l' siss nuur'+miiss ol-nu= ja siss he be.IPF.3SG be.IPF.3SG then young_man be-APP and then täüs+miiss $k u$ siss $[n u \quad$ krun't't'e $=$ aja-m'inõ $=$ grown_man when then those land.PL.GEN consolidate-AN

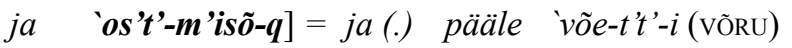
and buy-AN-PL.NOM and on take-IPS-IPF

'He was a young man back then and then a grown man when those land consolidation(s) and buyings were taken on.' 
The pluralized cases seem to imply that the process expressed by the base verb is conceptualized as a countable entity and refers to specific instantiations of that event or situation as opposed to the generic reading of a temporally unbounded type of event. As mine-ANs also display varying degrees of entrenchment, the pluralization can also be linked to conventionalization of certain action nominals. -mine derivations mostly represent a pure regular transposition from verbs (retaining the generic process or state reading) and are generally less likely to be lexicalized than deverbal action nominals with other less productive and semantically less regular suffixes, such as -us (supl-us 'a swim', joonist-us 'a drawing'), -is (küps-is 'a cookie'), -e (hüp-e 'a jump') etc. (for a comprehensive list, see Kasik 2004). Some of the -mine nouns (e.g. juhtu-mine '(a) happening; an event', ütle-mine '(a) saying') can be somewhat ambivalent in their interpretation even in a given context, others are, however, fully idiomatized and, given the context, construed as fixed expressions (e.g. söö-mine 'food', and-mine 'a present', maja+pida-mine 'household's, or school subjects, such as luge-mine 'reading', laul-mine 'singing'), which function as referential expressions without an overt process or state meaning, although the original semantic relationship between the base and the suffix is still transparent. The fact that derivational patterns used for action nominals can also render concrete nominals (denoting for example the product of an action, a group of people or a manner), is a widespread phenomenon in many languages (Comrie and Thompson 2007: 342) and is connected to metonymic meaning shifts (Haspelmath and Sims 2010: 254). Concrete nominals, in turn, are easily conceptualized as countable entities and are therefore also more prone to pluralization.

mine-ANs can take dependents typically occurring with nouns, such as adjectives (3) and demonstrative pronouns $(3,9,11)$, which are targets for noun agreement, and prenominal genitive attributes expressing the base verb's subject $(1,5)$ and object $(2,4,7,11)$. Manner and temporal adverbials can also be expressed as adjectival attributes (e.g. oma aja *keksutta-mine own.GEN time.GEN hop-AN 'the dancing of those times', Northeastern dialect), other adverbials and predicatives preserve their sentential form (Erelt et al. 1993: 269-270, Sahkai 2005:

5 These examples could, in principle, also be analyzed as a result of argument nominalization, in which case we could no longer speak about idiomatization and change in meaning. This is not a very likely path of development, however, since there is no reason why the -mine suffix would be used so regularly for creating action nominals, but at the same time would function as a means of object nominalization for only a limited number of verbs, which also do not seem to form any semantically coherent group. 
790-791). The NPs with action nominals as their heads are similar to noun phrases with non-derived noun heads, as agent ${ }^{6}$ and patient arguments are expressed as genitive "possessors". Generally, as the so-called Double-Possessive action nominal constructions are often avoided for the reason of possible ambiguity (Koptjevskaja-Tamm 2015: 654-655), in written Estonian, when both arguments are present, the patient becomes a genitive possessor and the agent is expressed by a pooltoblique (maja ehita-mine Peetri poolt house.GEN build-AN Peter.GEN by 'the building of a house by Peter', (Kasik 1968: 135, Erelt et al. 1993: 270, Erelt 2009: 21) or forms a compound with the action nominal (Peetri maja +ehita-mine Peter.GEN house.GEN+build-An 'Peter's housebuilding'), making argument marking in action nominal constructions the Ergative-Possessive or the Incorporating type, respectively (Koptjevskaja-Tamm 1993: 149-150, 188-190). The acceptability of the double genitives, where both arguments can occur in the NP as genitive possessors, has been advocated by Kehayov and Vihman (Kehayov and Vihman 2014: 1081), but only a few such examples can be found from the dialect corpus $(12)^{7}$. poolt-obliques in mine-AN phrases are not attested and most examples where both arguments are indeed expressed in a more or less canonical way (cf. next section) are cases where the patient forms a compound with the action nominal (13), but these compounds seem to be lexicalized to a certain degree and form one concept. However, as the transcriptions of the dialect recordings do not follow the traditional rules of orthography and token frequencies of compounds are low, it is difficult to assess the extent of conventionalization of these compounds in dialects.

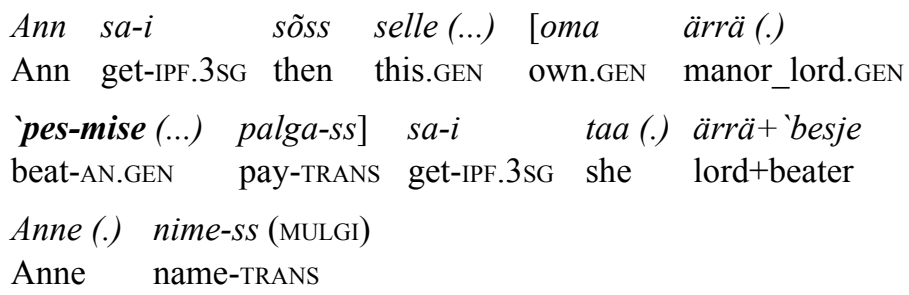

'Because of her beating the lord, Ann got the name Ann the lordbeater.'

6 For the purpose of simplicity, I will use the term agent to refer to both A and S arguments of a sentence.

7 This example, where the agent argument of the action nominal phrase is coreferential with the agent argument of the matrix clause, can in fact also be analyzed in many ways in terms of phrase composition: [[oma [ärra pesmise]] palgass], [[[oma ärra] pesmise] palgass], [oma [ärra pesmise] palgass] 
$\begin{array}{lllll}\text { (13) } & \text { üheksa } & \text { las- } t=\text { keik } k a t-s i-n= & \text { [ema } \\ \text { nine child-PART all cover-IPF-1SG mother.GEN }\end{array}$

'I covered all my nine children with my mother's weaving.'

kanga $=\boldsymbol{k u d u}$-mise-ga $]$ (INSULAR)

cloth.GEN weave-AN-COM

'I covered all my nine children with my mother's weaving.'

It is also plausible that the form and the overall realization of arguments is somewhat dependent on the syntactic function of the action nominal. For example, in Latvian, a -šana action nominal is more likely to appear without arguments when it is a genitive modifier than when it is used in subject or object function (Nau 2016: 68). For Estonian dialects, this will, however, remain a subject for closer investigation.

In all of the above presented contexts, mine-ANs were shown to reflect features mainly characteristic of nouns. The phrases in which a mine-AN is the head were also not the semantic core of the clause and could not therefore determine the existence and form of other elements in the sentence. I will next outline some features and contexts which differentiate action nominals from other nouns.

\section{2. mine-ANs as untypical nouns}

Although mine-ANs are essentially verbs functioning as nouns, they are not very prototypical nouns. The clearest indication of action nominals' non-nominal nature is the fact that they generally do not refer to manipulable entities, but preserve the base verb's situational meaning and refer to processes or states. As such, they are secondary means for expressing predication and are similar to non-finite verb forms belonging to the inflectional paradigm of verbs (Erelt et al. 1993: 232). Even though -mine derivation is morphologically completely regular, meaning it is possible to turn any verb into a noun simply by adding the suffix -mine to the (strong) stem of the verb, mine-ANs, like infinitives, inherit the lexical restrictions induced by the (normal) clause type, according to EKG (Erelt et al. 1993: 269) ${ }^{8}$.

8 The assumption that action nominals and non-finite verb forms are formed strictly from normal clauses is not without problems (Vare 1991). Also, the lexical restrictions might be genre-specific and closely linked to the syntactic environment of the action nominal. 
There are also other properties of mine-ANs that are not typically linked to other nouns and that reflect the sentential origin of phrases headed by action nominals. As action nominals can, in principle, inherit the full set of the predicate's arguments, complements and modifiers, they can combine with adverbial modifiers, which preserve their sentential form and many of which otherwise typically only occur with verbs. In the dialect data, adverbial modifiers include the complements of multi-word expressions (14-16) and adverbials expressing location (17), instrument (18), manner (19), time (20), state (21), quantity (22), and possessor (23).

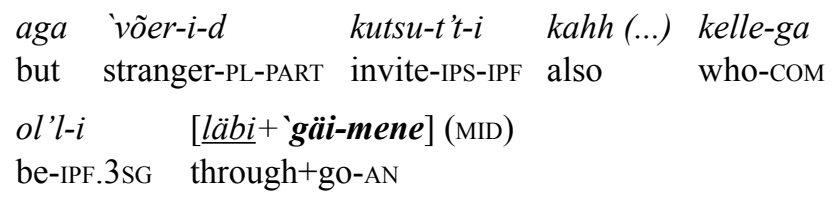

'But strangers were also invited, those, with whom one associated with.'

(15) kui $[\underline{\ddot{r} a}+$ dule-mine $]$ juo ol-i siis

when away+come-AN already be-IPF.3sg then

*tuo-d-i (.) ära (COASTAL)

bring-IPS-IPF PAR

'It was brought when people started to leave.'

(16) äga see pole siss [ [ $\underline{\text { valmis }}$ tege-mise] süi (INSULAR)

PAR this be.CNG PAR ready make-AN.GEN fault

'This is not the problem of preparation. '

(17) enne+vanaste (.) las-te-l ['istu-mis-t lauwa $=$ ääres]

in_former_times child-PL-ADE sit-AN-PART table.GEN POSTP

põl-n imette (WESTERN)

be-APP NEG

'In the former times, the children didn't sit at the table.'

(18) ja pole sääl änam siiss [’nua-ga 'löikka-mis-t]

and be.CNG there PAR then knife-COM cut-AN-PART

äga kivi tarvis äga mi-da-gid (INSULAR)

NEG stone.PART need NEG anything-PART-CLI

'And then one doesn't have to sharpen it with a knife or with a stone or anything' 
(19) ol'-i ju $i \quad k k e$ kõve-m rohi

be-IPF.3SG PAR PAR strong-CMP gunpowder

ja ei kannatta-nu (.) [nõnna+visi laadi-mes-t] (MID)

and NEG tolerate-APP like this load-AN-PART

'The gunpowder was quite strong and couldn't be loaded like this.'

$\begin{array}{llll}\text { (20) } \begin{array}{lll}u ̈ k s i+b a ̈ e n ’ i \\ \text { alone }\end{array} & \begin{array}{l}\text { [õsta } \\ \text { evening.GEN }\end{array} & \begin{array}{l}\text { pimeda-n } \\ \text { dark-INE }\end{array} & \begin{array}{c}\text { käi-mine } \\ \text { walk-AN }\end{array}\end{array}$

egä sii koa nal'ja as'i eij $=\tilde{o} l-l u \quad$ (EASTERN)

NEG this PAR joke.GEN matter NEG be-APP

'Walking alone in the evening in the dark was no laughing matter.'

(21) 'enne ol-i (.) [

before be-IPF.3SG soldier-TRANS take-AN be-IPF.3SG

$n i i+{ }^{\prime}$ viisti $=$ et $($ EASTERN $)$

like_this that

'Before, recruiting used to happen like this...'

(22) nied jättä-si-vad siis selle (.) [*liiga (.) *juo-mise]

they quit-IPF-3PL then this.GEN too_much drink-AN.GEN

maha kaa (NORTHEASTERN)

PAR also

'Then they also quit the excessive drinking.'

(23) põle nüid $[$ pere+me $=\underline{\text { kääst }}$ nori-mes-t] (MID)

be.CNG now landlord.GEN POSTP beg-AN-PART

'Now one doesn't have to beg the landlord.'

In nominalization, any adverbial can be attributized, whereas in other NPs, the range of possible adverbial modifiers is limited (Erelt et al. 1993: 122). Although nouns can, to a certain extent, be modified by adverbials expressing possession, accompaniment, oblique arguments, location, time, quantity, purpose or state (Erelt et al. 1993: 122), adverbial modifiers are still considered to be primarily verbal dependents (Vare 1991: 409) and their unrestricted combinations with action nominals can be considered an indication of the verbal nature of the latter (Haspelmath and Sims 2010: 258). 
When it comes to the realization of the predicate's arguments in -mine nominalization, the EKG (Erelt et al. 1993: 236, 270) and Erelt (2014: 238) state that the most significant difference between non-finite verb forms and action nominals is the fact that with non-finite forms, the object and its case alternation are preserved, whereas when nominalizing a verb, the object may be preserved only as a genitive attribute. Based on dialect data, this is not the case with all action nominals, however, and there are instances, where the object retains its sentential form both pre- $(24,25)$ and postpredicately $(26,27,28)$.

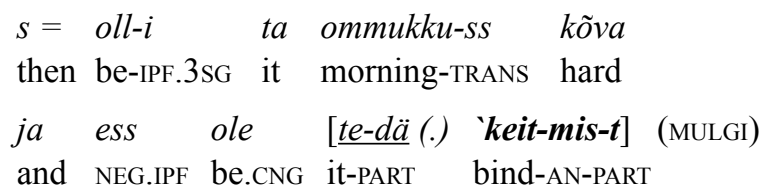

'Then it [the string] was hard by the morning and one couldn't bind it'

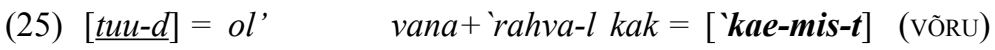

this-PART be.IPF.3Sg old+folk-ADE also look-AN-PART

'The old folk also had to look out for this.'

(26) või-b mets koa puhasta-da (.) põle

can-3SG forest.INE also clean-1 INF be.CNG

[kodo 'kan-mes-t $\quad[\underline{s e-d a} \quad \underline{\text { rimpsu }}]]$ (MID)

home.ILL carry-AN-PART this-PART trash-PART

'One can also clean them [the mushrooms] in the forest, then one doesn't have to carry all that trash home.'

(27) siis eij $=$ ol-nd $j u \quad$ ['müi-mes-t piima] ega ke-da-gi (MID) then NEG be-APP PAR sell-AN-PART milk.PART NEG anything-PART-CLI

'Back then the milk wasn't being sold or anything.'

(28) *enne *koittu ol-i (.) [veda-mine nei-d before dawn.PART be-IPF.3sg haul-AN.NOM they-PART

*välja] (COASTAL)

outside

'One had to haul them outside before dawn.' 
Already Wiedemann (2011: 495) noticed that verbal government can be retained in the realization of the underlying verb's arguments, and considered it an example of the verbal nature of mine-ANs. This is admittedly a very rare phenomenon in modern written language and is more characteristic of spoken language, also reflecting processing operations linked to nominalizing a verb. It is also likely not a feature that applies to action nominals in all syntactic environments and can only occur in certain constructions. All of the examples above are instantiations of the construction olema 'to be' $+\mathrm{Vmine}$ NOM/ PART, which is formally reminiscent of an existential or possessive clause, but whose main function is to emphasize process over agent either by omitting the agent $(24,26,27,28)$ or by turning it into an adessive experiencer (25). Obscuring the agent and the responsibility connected to it has also been considered a function of mine-ANs more generally (Kasik 2006a: 124-125). Some such constructions, however, also acquire modal meaning, enabling the constructions to express not only impersonalisation but also a judgement of obligation, permission or necessity concerning the process referred to by the action nominal in the nominative or partitive case. There are, however, no clear formal criteria for determining the presence and type of speaker stance marking and for differentiating between the modal and impersonal constructions in the dialect data. Both the partitive and the nominative action nominals occur in both impersonal and modal constructions and both also in affirmative and negative clauses. In negative clauses, however, the nominative $(29)^{9}$ would be highly untypical were it a subject of an existential clause. (Pilvik 2016)

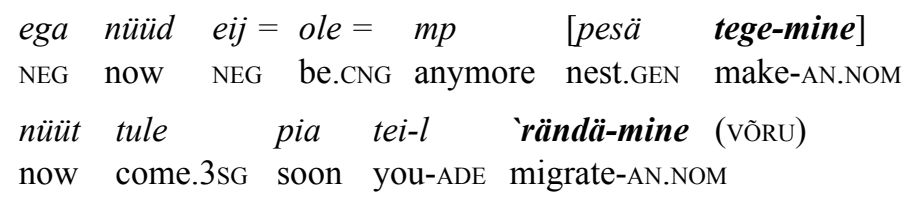

(about talking to birds) 'There is no nestmaking anymore [you should not be making your nests anymore], you'll be migrating soon.'

Similar tendencies of both argument and action nominal case marking can be noticed in other Finnic languages. In Finnish, the corre-

9 As the example suggests, in addition to the copula, other grammatical verbs (such as tulema 'to come') can occur in the construction as well, modifying the aspect of the construction, although they do so very rarely. 
sponding minen-noun can also take an object (Jos Anttia on uskominen 'If one is to believe Antti') only in the necessive construction, but not otherwise (Hakulinen et al. 2004). The same construction (called a debitive construction) is grammaticalized also in Livonian (mi'nnõn um mu'rtõ pidāmõst il si'n 'I have to take care of you', Viitso 2008: 344). It has been suggested that these constructions go back to the allegedly proto-Finnic construction $\mathrm{A}_{\mathrm{GEN} / \mathrm{DAT} / \mathrm{ADE}}$ on $\mathrm{V}$ mine $e_{\mathrm{NOM} / \mathrm{PART}} \mathrm{b}_{\mathrm{NOM} / \mathrm{ACC} /}$ ${ }_{\text {PART }}{ }^{10}$ (Grünthal 1941: 177-179), where A stands for the agent and $b$ for patient and which has been relatively prone to changes in word order $\left(\mathrm{A}_{\mathrm{GEN} / \mathrm{DAT} / \mathrm{ADE}}\right.$ on $\mathrm{V}$ mine NOM $/ \mathrm{PART} \mathrm{b}_{\mathrm{NOM} / \mathrm{ACC} / \mathrm{PART}} \rightarrow \mathrm{A}_{\mathrm{GEN} / \mathrm{DAT} / \mathrm{ADE}}$ on $\mathrm{b}_{\mathrm{NOM} / \mathrm{ACC} / \mathrm{PART}} \mathrm{V}$ mine $e_{\mathrm{NOM} / \mathrm{PART}} \rightarrow \mathrm{b}_{\mathrm{NOM}}$ on $\mathrm{A}_{\mathrm{GEN} / \mathrm{DAT} / \mathrm{ADE}} \mathrm{V}$ mine $e_{\mathrm{NOM} /}$ PART). The impersonal-modal constructions are thus connected to the following passive constructions, where the patient is promoted to the subject position and which have a modal meaning as well. The agent can be omitted $(30,31)$ or be added as an adessive argument $(32)$.

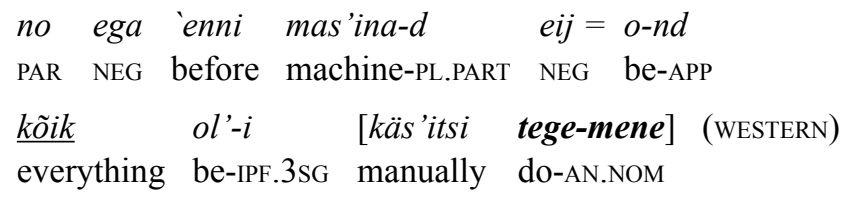

'Before, there were no machines, everything had to be done manually.'

(31) $\underline{\text { sie }}$

$\begin{array}{lllll}\text { sie } & \text { ol-i } & \text { kaa } & \text { [salaea *tuo-mine }] & \text { jaa (.) } \\ \text { this } & \text { be.IPF.3SG } & \text { also } & \text { secretly bring-AN.NOM yes } \\ \text { se-da } & \text { avalikkult } & \text { ei } & \text { *las-tu *tuu-wa } & \text { (COASTAL) } \\ \text { this-PART } & \text { publicly } & \text { NEG } & \text { let-PPP bring-1INF } & \end{array}$

'This had to be brought in secretly too, yes, you could not bring it in public.'

(32) $t u u=o l$ ' vana+' 'rahva-l $k a \quad$ 'kae-mine (võRU)

this be-IPF.3sG old+folk-ADE also look-AN.NOM

'The old folk also have to look out for this.'

The patient can also be expressed outside of the NP in other cases. In

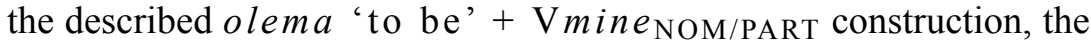

10 The construction schema has been generalized to fit all the Finnic languages. Grünthal's original schema (Grünthal 1941: 178) was A:n on tekeminen t. tekemistä b, which he described as characteristic of Finnish, Karelian and Estonian; in Livonian, the object in the accusative was considered a Latvian influence. 
patient can be expressed in the comitative case $(33,34)$ or on rare occasions even as an adessive inanimate "experiencer" $(35,36)$, in which case it seems impossible to add an agent argument in any form.

(33)

minu-l eij $=$ olo $\quad$ enämp tõnõ + gõrt $\underline{\text { sinu-gä }}=$ ss (.)

I-ADE NEG be.CNG anymore other_time you-COM then

'kän' $\boldsymbol{g}$-mis-t (TARTU)

put_shoes_on-AN-PART

'Then another time, I don't have to put your shoes on you anymore.'

(34) ol'-i ikke [oma (.) 'óppi-mene] koa nände-ga (WESTERN)

be-IPF.3SG PAR much study-AN.NOM also they-COM

'You had to study them a lot.'

(35) aga lina-l ei o-nd (.) [nisuk-st rohi-mes-t] jüst (WESTERN) but flax-ADE NEG be-APP like_this-PART weed-AN-PART PAR

'But flax didn't have to be weeded like that.'

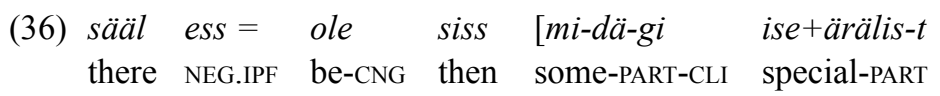

'mat-mis-t] tatll (MULGI)

bury-AN-PART it-ADE

'It is not buried in any special way.'

As the impersonal-modal construction has already illustrated, in connection to many of the untypical properties of mine-ANs, we can actually speak about instantiations of constructions with their own semantic and syntactic properties. These are linguistic structures in which the action nominal functions as the semantic and syntactic core of the clause, triggering also the realization of other elements in that clause, and the finite verb is left to express the grammatical functions (Muischnek and Sahkai 2010: 296). There are several verbs in Estonian (and other Finnic languages), which, in addition to serving as lexical verbs, can also be used as grammatical verbs. In such cases, they specify either the tense, voice or mood of the predicate and the lexical content of the predicate itself is expressed by infinitives or nominalizations. Constructions with nominalized complements include finite verbs such as olema 'to be', tahtma 'to want', saama 'to get', minema 'to go' etc. In Estonian linguistics, these constructions have been analysed as either 
lexicalized composites (similar to phrasal verbs), combinations of a finite verb and its dependent, or periphrastic verb forms (see Sahkai 2005 and 2011 for a detailed discussion). The phenomenon where nouns combine with verbs, forming a verbal compound of phrasal nature (instead of a strict compound with a word status), has also been called quasi-incorporation (Dahl 2004, Booij 2009). In these constructions, the noun (or a noun phrase) can receive or retain case or number marking, thereby having specific formal properties, while entailing the semantics of incorporation. (Booij 2009: 7) As Booij (2009: 7) puts it: "Combinations of $\mathrm{N}$ and $\mathrm{V}$ in quasi-incorporation are phrasal predicates that instantiate a specific construction with syntactic and semantic properties of its own." In addition to the already discussed olema 'to be' $+\mathrm{V}$ mine NOM/PART $_{\text {P }}$ expressions, there are several other constructions in Estonian dialects where the action nominals get (quasi-)incorporated and where the whole construction functions as a complex predicate. In what follows, I will give a brief overview of the constructions attested in the dialect corpus and leave a more detailed analysis of them, which they undoubtedly deserve, for other articles to come. I will first present examples of the construction in question and then describe their properties based on the dialect examples and previous studies, if such are available. The productivity of the action nominal constructions in dialect data, however, is hard to assess, since action nominals are quite rare in the dialect corpus (compared to, for example, infinitives) and type frequencies of particular patterns are low.

\subsection{1 minema 'to go' $+V$ mine $_{A L L}$}

(37) $e k s=t a \quad$ 'tuula-mese-le läk-s (MID)
PAR it.NOM winnow-AN-ALL go-IPF.3SG
'It [the grain] was going to be winnowed.'

The written-language use of this construction, which is used for passivization, has been quite thoroughly described by Heete Sahkai and Kadri Muischnek (Sahkai 2005, 2011, Muischnek and Sahkai 2010). The patient of the process expressed by the action nominal is the subject in the nominative case and therefore the action nominal in the construction can only be formed from transitive verbs. The underlying verbs of the action nominal typically express change of state, mental action, change of possession, making or creating something 
(Muischnek and Sahkai 2010: 307). The construction has an ingressive ${ }^{11}$ meaning, which is preserved also in the past tense forms (Sahkai 2005: 798-799). Similar properties, except for the ingressive reading, apply to the progressive passive construction olema 'to be' $+\mathrm{Vmine}_{\mathrm{ADE}}$ (e.g. $t a$ on tuula-mise-l it.NOM be.PR.3SG winnow-AN-ADE 'it [the grain] is being winnowed'). This construction, however, was not attested in the dialect corpus.

There are also other ingressive constructions with mine-ANs in lative cases in Estonian, which differ in terms of the active (asuma 'to set to' $+\mathrm{V}$ mine $\left._{\mathrm{ALL}}\right)$ or passive reading and might also mark the speaker's stance (kuuluma 'to belong to' $+\mathrm{Vmine}_{\mathrm{ALL}}$ ) and in which the action nominal can often be replaced with an infinitive (Sahkai 2005: 800, Erelt 2014: 245). However, such constructions are also not present in the dialect data used in this article, and it is therefore difficult to characterize them in more detail. Due to the ingressive meaning of the construction minema 'to go' $+\mathrm{Vmine}_{\mathrm{ALL}}$, brought on not only by the use of the light verb minema 'to go' but by the whole construction (Sahkai 2005: 800), it is linked also to the next construction.

2.2.2. minema 'to go' $+V$ mine $e_{\text {TRANS }}$
(38) siis lähe-b ta [üles 'kisku-mise-ks] (WESTERN) then go-3sg it.GEN up tear-AN-TRANS
'Then it will be torn up'

This construction is an impersonal construction with no grammatical subject, where the action nominal in the translative case can be formed from both transitive and intransitive verbs (e.g. siis läheb jooksmiseks 'Then there will be running') and the construction expresses the beginning of the process expressed by the action nominal. The agent can be omitted as in example 38 or be expressed by an adessive argument (Erelt 2014: 246).

\footnotetext{
11 I will use the term 'ingressive' to refer to the notion of the beginning of activities or states, covering also the terms 'inchoative' and 'inceptive'.
} 


\subsection{3. olema 'to be' $+V$ mine $_{A D E} / V$ mine $_{G E N}$ peal 'on'}

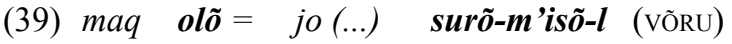

I be.1sG already die-AN-ADE

'I am already dying.'

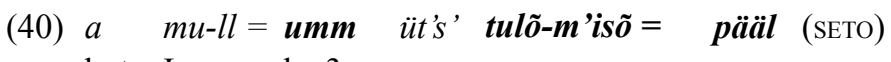

but I-ADE be.3SG one come-AN.GEN POSTP

'But I have one coming.'

Another construction linked to the progressive passive construction referred to above is the progressive active construction. This construction usually expresses imminence $(39,40)$, but is said to occasionally also mark a durational process (Neetar 1988: 42). The subject is coreferential with the actor of the nominalized verb and the action nominal can be substituted with the inessive form of the $m a$-infinitive (or the '2nd infinitive') (Erelt 2014: 246). It therefore differs from the passive construction mentioned above (Sahkai 2005: 792). The adessive action nominal in this construction is said to be especially common in Tartu and Võru dialects (Neetar 1988: 42-44) and the analytic adpositional alternative in western dialects (Neetar 1988: 44), but outside of this construction, the use of analytic adposition constructions instead of synthetic case forms has been linked to both Western dialect and southern dialects (Palmeos 1985: 15, Klavan et al. 2015).

\subsection{4 tahtma 'to want' $+V$ mine $_{P A R T}(+$ saada 'to get') \\ (41) need 'taht-si-d köik 'törva-mis-t need these.NOM want-IPF-3PL all tar-AN-PART these.NOM \\ 'These things all needed to be tarred.'}

A quite common action nominal construction, in which the patient argument gets promoted to subject status, is the modal passive construction tahtma 'to want' + Vmine $_{\mathrm{PART}}(+$ saada 'to get'). This construction expresses the necessity of performing the action specified by the action nominal on the patient functioning as the grammatical subject. The action nominal can be replaced with the $d a$-infinitive (' 1 st 
infinitive') and mainly in the western dialects, the construction can additionally accommodate the $d a$-infinitive form of the verb saama 'to get' (Neetar 1988: 37). For the passive reading, the action nominal has to be formed from a transitive verb. In the active counterpart (42), where the subject refers to the actor, the constructional analysis is not necessary and instead, we can simply speak about the finite verb tahtma 'to want' and its object.

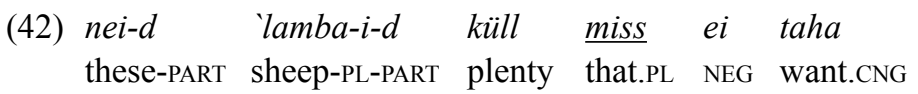

'easti 'niit-mis-t (INSULAR)

really shear-AN-PART

'There are plenty of sheep that don't really want to be sheared.'

\subsubsection{Emphatic constructions (V1 + V1mine)}

An interesting and formally quite diverse set of constructions in dialects are emphatic constructions, where the finite verb and the action nominal are formed from identical bases and emphasize either the continuation $(43,44)$ or the intensity $(45,46)$ of the process (Neetar 1988: 44-45).

$\begin{array}{lllll}\text { pasun } & \boldsymbol{p u h u}-\boldsymbol{b} & {[\tilde{o m a}} & \text { 'puhku-mis-t}] & \text { (EASTERN) } \\ \text { horn } & \text { blow-3SG } & \text { OWn.GEN } & \text { blow-AN-PART }\end{array}$

'The horn is blowing its blowing.'

$\begin{array}{lllll}j a & \text { pii-d } & \text { si-dä } & \text { [videlikku } & \text { pidä-mis-t }] \\ \text { and } & \text { pass-IPF.3PL } & \text { this-PART } & \text { twilight_time.GEN } & \text { pass-AN-PART } \\ \text { viel } & \text { igä } & \text { *neljäs }^{*} \text { *ä̈ivä } & \text { *ehtutti } & \text { (COASTAL) } \\ \text { PAR } & \text { every.GEN } & \text { thursday.GEN } & \text { in_evenings }\end{array}$

'And on thursday evenings [they] passed time during the twilight.'

$\begin{array}{lllll}\text { (45) 'sõima-s } y k s \quad[' s \tilde{o} i m a-m ' i s \tilde{o} & \text { 'muиdu] } & \text { (SETO) }\end{array}$

curse-IPF.3SG PAR curse-AN.GEN POSTP

'Cursed heavily.' 
(46) ja mea teeni periss (.) ['tiin-mise 'muudu] (MULGI) and I serve.1sG quite serve-AN.GEN POSTP

'And I serve [him] tirelessly.'

It is difficult to say, however, based on the sparse data from the dialect corpus, which range of syntactic combinations such constructions cover and whether there are any lexical restrictions.

\subsubsection{Colorative constructions $\left(V 1+V 2\right.$ mine $\left._{P A R T}\right)$}

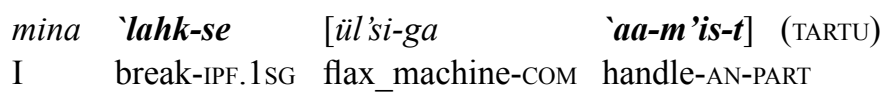

'I worked with the flax machine.'

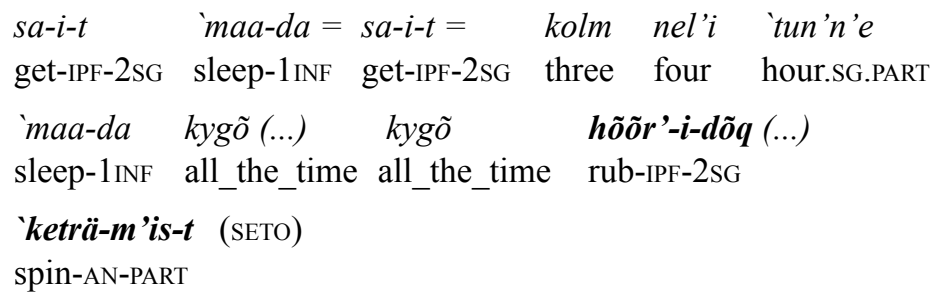

'You only got to sleep three-four hours, you were spinning all the time.'

There are also expressions in the dialect corpus that can be considered colorative constructions (which are notoriously difficult to translate in an adequate manner), in which the action nominal expresses the activity and the finite element specifies the manner, intensity or duration of doing that activity. The action nominal can also be replaced with the $d a$-infinitive. In the dialect corpus, only constructions with the finite verbs lõhkuma 'to break' and hõ̃ruma 'to rub' occur, but descriptive finite verbs include a wide range of verbs, which can have their own lexical meaning (vehkima 'to flail') or be only used in the colorative constructions (e.g. vihtuma tantsidaltantsimist 'to dance (actively)').

\subsubsection{Converb constructions}

In addition to action nominal constructions that function as complex predicates, there are other expressions that are similar to converb constructions (Erelt 2009: 24), i.e. nonfinite verb forms, which function 
as verbal adverbs ${ }^{12}$ and modify verbs, clauses or sentences, but generally not nouns or noun phrases (Haspelmath 1995: 7). Here, I consider converbs to be free adverbial modifiers, following Ylikoski (2003: 197-198). Both converb constructions and mine-AN expressions in the same functions are non-referential and processual. The action nominals can not, therefore, be easily pluralized in these constructions. (Sahkai 2009: 377) Due to limitations of space in this article, I will here only briefly illustrate the converbal nature of the action nominals, although a more detailed analysis of such constructions in dialects would certainly be due, especially since there is a well-attested cross-linguistic tendency for new infinitives and converbs to develop from case-marked action nominals (Koptjevskaja-Tamm 1993: 44, Ylikoski 2003: 199, 203).

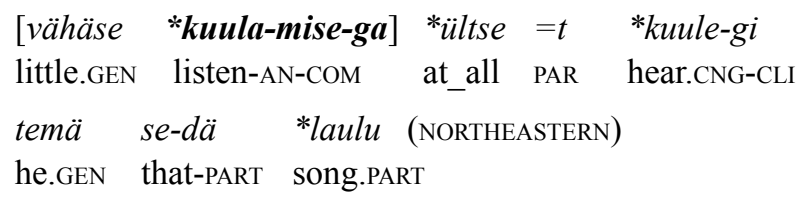

'With little listening one can't hear its [the bird's] singing at all.'

Example 49 is a construction in which the actor of the action nominal is coreferential with the actor of the main clause. As a result, the action nominal construction has to leave the subject obligatorily implicit, much as many converbs do (Haspelmath 1995: 10). The action nominal construction can also be replaced by a -des gerundive, in which case the adjectival modifier would be turned into an adverbial modifier (vähe kuulates).

As another example of action nominal constructions similar to converb expressions, Heete Sahkai $(2006,2009,2011)$ has described the so-called adessive manner and cause adverbials (AMCs) in written Estonian (for example, Tegime seda Mardi teadmisel 'We did this with Mart's knowing', cf. Sahkai 2009: 376-377), the negative counterpart of which would be a fixed transitive different-subject converb construction with the suffix -mata (Mardi teadmata 'without Mart's knowing'). The constructions consist of a genitive attribute and an action nominal in the adessive case, and they display various features not predicted by the properties of the action nominals as nominal phrase heads. For

12 There are some problems with the notion "verbal adverb" as explained in Ylikoski (2003: 195-196), since adverbs are not the only word class with the ability to occupy an adverbial position. 
example, the genitive attribute can only express the subject and not the object. (Sahkai 2009: 375-376)

As shown in this and the previous section, mine-ANs, in addition to being used as typical nouns, can also exhibit properties characteristic of a verbal paradigm, and occur in functions common to non-finite verb forms. As adverbials, they can serve as converbs, and in periphrastic constructions, they either form a complex predicate with a finite element by themselves or share the complementing role of infinitives. This is in line with Ylikoski's (2003: 200) claim that the functions of action nominals distribute over infinitives and converbs.

\section{3. mine-ANs in discourse}

A further point, which in a way diverges from the issues discussed so far, concerns the use of mine-ANs in discourse. The dialect corpus is based on semi-structured interviews in which the informants are asked to talk about past events, customs, work, and their everyday lives. A peculiarity of the mine-ANs in the dialect corpus data is their repetitive uses in discourse. In addition to being a means for anaphoric referencing, as in examples 50 and 51, mine-ANs in these interviews are often syntactically unbounded and seem to be used by the informants to help to relax the processing load or to provide time for planning the utterance, whether then by reflecting the form in the interviewer's question (52), or creating a topical reference for the speaker's own following utterance (53).

\begin{tabular}{|c|c|c|c|c|c|}
\hline $\begin{array}{cl}\text { nõnna kudas } & \text { taa } \\
\text { this_way how } & \text { it.GEN }\end{array}$ & $\begin{array}{l}\text { karv } \\
\text { hair }\end{array}$ & $\begin{array}{ll}\text { ol-i } i & \text { siiss } \\
\text { be-IPF.3SG } & \text { then }\end{array}$ & $\begin{array}{l}\text { seda+mo } \\
\text { this_way }\end{array}$ & & $\begin{array}{l}t \ddot{a}-d a \\
\text { it-PAR }\end{array}$ \\
\hline $\begin{array}{ll}\dddot{u i i} i-t t-i(\ldots) & j a h h(\ldots) \\
\text { call-IPS-IPF } & \text { yes }\end{array}$ & $\begin{array}{l}j a a \\
\text { and }\end{array}$ & $\begin{array}{l}\text { 'mõist-si-d } \\
\text { understand-IPF-3PL }\end{array}$ & $\begin{array}{l}\text { koo } \\
\text { also }\end{array}$ & $\begin{array}{l}{[s e-s t} \\
\text { this- }\end{array}$ & \\
\hline
\end{tabular}

'And they [the bulls] were called by the [color of their] hair. Yes. And they also understood that calling.'

(51) Int: a kuda se-da roo kattus-t teha-kse but how this-PART reed.GEN rOof-PART make-IPS.PR 'But how is the thatched roof made?' 
Inf: nohh see (.) [see kattuse+tege-mene] ol-i koa

PAR this this roof.GEN + make-AN be-IPF.3SG also

'seohke asi (...) (WESTERN)

like_this thing

'Well, the roofmaking went like...'

(52) Int: a kudass [see `arja-mine] nagu käi-b

but how this ridge-AN PAR go-3SG

'But how is the roofridging done?'

Inf: 'arja-me-

'Ridgi-'

Int: kattuse 'arja-mine

roof.GEN ridge-AN

'Roofridging.'

Inf: 'arja-mene (.) nohh ja siis ol-i 'iseohke asi(.) ridge-AN PAR and then be-IPF.3SG like_this thing mõne-d ‘arja-si-d oma-l (.) jälle (...) $e$ some-PL.NOM ridge-IPF.3PL OWn-ADE PAR PAR rugi+põhu-ga (...) (WESTERN)

rye.GEN+litter-COM

'Ridging... well, and then it went like... some ridged theirs with rye litter.'

(53) mis = ma nüid (--) mis = mu-l nüid 'miil-i tule-b (...) what I now what I-ADE now mind-ILL come-3SG noo $=$ ja $\quad$ sõss (...) haa (.) 'keträ-mine (...) siss tull-i PAR and then PAR spin-AN then come-IPF.3sG 'keträ-mine (...) kui lina te-tt oll-i sui-tt-i na spin-AN when flax do-PPP be-IPF.3sG hackle-IPS-IPF they arja-st läbi (...) ja siss tull-i 'keträ-mine (...) neli brush-ELA POSTP and then come-IPF.3SG spin-AN four viis' nais- $t$ oll-i kuss suure talu-de five woman-PART be-IPF.3SG where big.PL.NOM farm-PL.NOM 
$\begin{array}{llll}\text { oll-i } & \text { kedrä-si-v (.) } & \text { tal'v läbi (MULGI) } \\ \text { be-IPF.3PL } & \text { spin-IPF-3PL } & \text { winter } & \text { POSTP }\end{array}$

'Now what do I... Now what else comes to mind... Well, and then... spinning. Then came the spinning. When the flax was done, it was hackled with a brush and then came the spinning. There were four-five women spinning through the whole winter, when there were big farms.'

The importance of similar repetitiveness in conversational interaction has been stressed especially by discourse analysts and conversation analysts (Szmrecsanyi 2005). mine-ANs in the dialect corpus seem to be also quite prone to persistence effects, lexical as well as syntactic, meaning that speakers will re-use a construction they have recently heard or used for either creating and processing (elliptical) utterances, to open up question-answer pairs, or for many other reasons. (Szmrecsanyi 2005, Gries 2005) In the context of the data used in this article this means that the realization of the action nominals produced by the informants as well as their choice to present a situation as a nominal constituent in the sentence instead of a verbal one in the first place is always somewhat also affected by what has been said in the previous discourse. However, it is difficult, to say the least, to resolve all the possible motivations for repetition using corpus data (Szmrecsanyi 2005: 144).

\section{Summary}

In the article, I described Estonian -mine action nominals (mineANs) in Estonian dialect corpus data with respect to their properties both typical and untypical for regular nouns and the syntactic contexts in which the action nominals occur. I also briefly discussed their functions in discourse.

mine-ANs are an example of intercategorial phenomena, displaying features which associate them with both the nominal and verbal domains. By their inflectional morphology and many of their internal and external syntactic properties, action nominals can be considered typical nouns. They are often used in functions characteristic of noun phrases (e.g. arguments of verbs, genitive modifiers of nouns, complements of adpositions, both elements of predicative expressions) and the internal organization of the noun phrase headed by the action nominal is also much like the structure of an NP headed by any other noun. Their semantics, some idiosyncracies in both their internal and external 
syntax, and high combinatorial and functional potential, however, link them to the verbal domain along with other non-finite verb forms. In various constructions, mine-ANs are indeed very similar to and even replaceable by non-finite verb forms, such as $d a$ - and $m a$-infinitives, and they also serve converbal functions. In unedited, spoken regional language, the marking of the agent and patient argument of the action nominal in the constructions may differ from the one of the expected prenominal modifier or oblique poolt construction. For example, the general claim that the object may occur only as a genitive attribute in the nominalized NP and not retain its sentential form, which has been considered to be the main feature distinguishing mine-ANs from non-finite verb forms, is challenged based on dialect data. In certain constructions, the patient argument can be expressed also in the partitive case or outside the NP as an adessive "experiencer". As for the functions of mine-AN constructions in dialects, there are many. The periphrastic verb constructions are often used to highlight the process, by allowing the agent to remain unexpressed or by demoting it to an unprototypical position. This is in line with impersonal and passive verb constructions. The action nominal constructions can also be used to express modal, aspectual or other facets of situations.

All this implies that mine-ANs can not and indeed do not have to be defined through the categorial meaning of some word class. They are simply one linguistic means among many that have the ability to express a situational relationship and it is the syntactic environment that determines the way a situation is presented. I hope to have shown that mine-ANs are best described from a multifunctional perspective. minenominalization is not only something that happens in or is reserved to lexicon and morphology, but it has consequences also for syntax and semantics, and it seems to fulfill a purpose even in discourse as mineANs are frequently used for processing and planning utterances in conversational interaction.

There are still many aspects of mine-ANs that require further research. For example, further investigation is needed in terms of the distribution and combinations of specific case forms and lexeme groups. Another unanswered question is whether the realization of the verb's arguments is dependent on the form or function of the action nominal. As mine-ANs are not an isolated phenomena and are a part of a greater linguistic system, comparing -mine constructions with other functionally competing expressions as well as contrasting -mine nouns with action nominals with other suffixes might shed more light on the nature of action nominals whose surface was only scratched in this article. 


\title{
Acknowledgements
}

This study was supported by the Estonian Research Council grant PUT (90), and by the (European Union) European Regional Development Fund (Centre of Excellence in Estonian Studies).

\author{
Address \\ Maarja-Liisa Pilvik \\ Institute of Estonian and General Linguistics \\ University of Tartu \\ Jakobi 2 \\ 51014 Tartu, Estonia \\ E-mail: maarja-liisa.pilvik@ut.ee
}

\begin{abstract}
Abbreviations
1INF - 1st infinitive ( $d a$-infinitive), ACC - accusative, ADE - adessive, ALL - allative, AN - action nominal, APP - active past participle, CLI - clitic, CMP - comparative, CNG - connegative, COM - comitative, DAT - dative, ELA - elative, GEN - genitive, ILL - illative, INE - inessive, IPF - imperfect tense, IPS - impersonal mood, NEG - negation, NOM - nominative, PAR particle, PART - partitive, PL - plural, POSTP - postposition, PPP - passive past participle, PR - present tense, PREP - preposition, SG - singular, TRANS - translative
\end{abstract}

\section{References}

Booij, Geert (2009) “A constructional analysis of quasi-incorporation in Dutch". Gengo Kenkyu 135, 5-28.

Comrie, Bernard (1976) "The syntax of action nominals: a cross-language study". Lingua 40, 177-201.

Comrie, Bernard and Sandra A. Thompson (2007) "Lexical nominalization". In Timothy Shopen, ed. Language typology and syntactic description, Vol. 3: Grammatical categories and the lexicon, 334-381. Cambridge: Cambridge University Press.

Dahl, Östen (2004) The growth and maintenance of linguistic complexity. Amsterdam: John Benjamins.

De Smet, Hendrik (2008) "Functional motivations in the development of nominal and verbal gerunds in Middle English and Early Modern English”. English Language and Linguistics 12, 55-102. 
Erelt, Mati (2009) "Typological overview of Estonian syntax". STUF - Language Typology and Universals 62, 1/2, 2-28.

Erelt, Mati (2014) Eesti keele lauseõpetus. Komplekslause. Tartu: University of Tartu.

Erelt, Mati, Reet Kasik, Helle Metslang, Henno Rajandi, Kristiina Ross, Henn Saari, Kaja Tael, and Silvi Vare (1993) Eesti keele grammatika. II. Süntaks. Kiri. Tallinn: Eesti Teaduste Akadeemia Keele ja Kirjanduse Instituut.

Erelt, Mati, Reet Kasik, Helle Metslang, Henno Rajandi, Kristiina Ross, Henn Saari, Kaja Tael, and Silvi Vare (1995) Eesti keele grammatika. I. Morfoloogia. Sõnamoodustus. Tallinn: Eesti Teaduste Akadeemia Keele ja Kirjanduse Instituut.

Fanego, Teresa (2004) "On reanalysis and actualization in syntactic change: the rise and development of English verbal gerunds". Diachronica 21, 1, 5-55.

Gries, Stefan Thomas (2005) "Syntactic priming: A corpus-based approach". Journal of Psycholinguistic Research 34, 4, 365-399.

Grünthal, Willem (1941) Itämerensuomalaisten kielten yksikön nominatiivi objektin edustajana aktiivin yhteydessä: lauseopillinen tutkimuskoe. Helsinki.

Hakulinen, Auli, Maria Vilkuna, Riitta Korhonen, Vesa Koivisto, Tarja Riitta Heinonen, and Irja Alho (2004) Iso suomen kielioppi. Helsinki: Suomalaisen Kirjallisuuden Seura.

Haspelmath, Martin (1993) A grammar of Lezgian. (Mouton Grammar Library, 9.) Berlin: Mouton de Gruyter.

Haspelmath, Martin (1995) "The converb as a cross-linguistically valid category". In Martin Haspelmath and Ekkehard König, eds. Converbs in cross-linguistic perspective, 1-55. Berlin: Mouton de Gruyter.

Haspelmath, Martin and Andrea D. Sims (2010) Understanding morphology. 2nd ed. (Understanding Language Series.) London: Routledge.

Hopper, Paul J. and Sandra A. Thompson (1984) "The discourse basis for lexical categories in universal grammar". Language 60, 4, 703-752.

Kasik, Reet (1968) "Omastavalise täiendi subjektilisusest ja objektilisusest minekonstruktsioonis". In Keel ja struktuur 2, 125-139. Tartu: Tartu Riiklik Ülikool.

Kasik, Reet (1975) "Verbide ja verbaalsubstantiivide tuletusvahekorrad tänapäeva eesti keeles". In Keele modelleerimise probleeme 5, 3-162. (Tartu Riikliku Ülikooli toimetised, 363.) Tartu.

Kasik, Reet (2004) Eesti keele sõnatuletus. 2nd ed. Tartu: University of Tartu Press.

Kasik, Reet (2006a) "Nominalisatsioon meediauudiste tekstimoodustusvõttena". Keel ja Kirjandus 2, 122-134.

Kasik, Reet (2006b) "Nominaliseeritud protsessi agent meediauudistes". Emakeele Seltsi aastaraamat 51, 21-37.

Kasik, Reet (2015) Sõnamoodustus. (Eesti keele varamu, 1.) Tartu: Tartu Ülikooli Kirjastus.

Kehayov, Petar and Virve-Anneli Vihman (2014) "The lure of lability: a synchronic and diachronic investigation of the labile patterns in Estonian". Linguistics: An Interdisciplinary Journal of the Language Sciences 52, 4, 1061-1105.

Kerge, Krista (2001) “Action nouns on -mine in Estonian grammar and lexicon”. In Jarkko Niemi and Janne Heikkinen, eds. Nordic and Baltic morphology: papers from a NorFA course, Tartu, June 2000, 34-45. Joensuu: University of Joensuu. 
Kerge, Krista (2003) “Keele variatiivsus ja mine-tuletus allkeelte süntaktilise keerukuse tegurina”. Doctoral Thesis. Tallinn: Tallinna Ülikool.

Klavan, Jane, Maarja-Liisa Pilvik, and Kristel Uiboaed (2015) "The use of multivariate statistical classification models for predicting constructional choice in spoken, nonstandard varieties of Estonian". SKY Journal of Linguistics 28, 187-224.

Koptjevskaja-Tamm, Maria (1993) Nominalizations. London: Routledge.

Koptjevskaja-Tamm, Maria (2006) "Nominalization”. In Keith Brown, ed. Encylopedia of language and linguistics, 2nd ed., 8, 652-659. Amsterdam: Elsevier.

Koptjevskaja-Tamm, Maria (2015) “Action nouns” In Peter O. Müller, Ingeborg Ohnheiser, Susan Olsen, and Franz Rainer, eds. Word formation: an international handbook of the languages of Europe, 1195-2009. Berlin: Mouton de Gruyter.

Mackenzie, J. Lachlan (1985) "Nominalization and valency reduction". In A. Machtelt Bolkestein, Casper De Groot, and J. Lachlan Mackenzie, eds. Predicates and terms in functional grammar, 29-47. Dordrecht: Floris Publications.

Malchukov, Andrej L. (2004) Nominalization/verbalization: constraining a typology of transcategorial operations. München: Lincom Europa.

Malchukov, Andrej L. (2006) "Constraining nominalization: function/form competition”. Linguistics 44, 5, 973-1008.

Muischnek, Kadri and Heete Sahkai (2010) "Liitpredikaadid leksikoni-grammatika kontiinumil: konstruktsioonide produktiivsusest verbiga 'minema' moodustatud liitpredikaatide näitel”. Journal of Estonian and Finno-Ugric Linguistics 1, 2, 295-316.

Nau, Nicole (2016) "Argument realization in Latvian action nominal constructions: a corpus and text based investigation". In Axel Holvoet and Nicole Nau, eds. Argument realization in Baltic, 1-34. Amsterdam: John Benjamins.

Neetar, Helmi (1988) "Mõnest teonimekonstruktsioonist eesti murretes". Emakeele Seltsi aastaraamat 32, 36-45.

Noonan, Michael (1997) "Versatile nominalizations". In Joan Bybee, John Haiman, and Sandra A. Thompson, eds. Essays on language function and language type: dedicated to T. Givón, 373-394. Amsterdam: John Benjamins.

Palmeos, Paula (1985) Eesti keele grammatika II. Kaassõna. Tartu: TRÜ trükikoda.

Pilvik, Maarja-Liisa (2016) “Olema + Vmine konstruktsioonid eesti murretes”. Keel ja Kirjandus 6, 429-446.

Sahkai, Heete (2005) “Teonimi perifrastilises verbivormis". Keel ja Kirjandus 10, 790-807.

Sahkai, Heete (2006) "Konstruktsioonipõhise keelekirjelduse võimalustest adessiivse viisi- ja põhjusmääruse näitel". Keel ja Kirjandus 10, 816-831.

Sahkai, Heete (2009) "Implications of a construction for the theory of grammaticalization: Estonian adessive manner and cause adverbials". Trames 13, 4, 374-400.

Sahkai, Heete (2011) Teine grammatika: eesti keele teonimede süntaks konstruktsioonipõhises perspektiivis. (Tallinn University dissertations on humanities, 25.) Tallinn: Tallinna Ülikool.

Szmrecsanyi, Benedikt (2005) "Language users as creatures of habit: a corpus-linguistic analysis of persistence in spoken English". Corpus Linguistics and Linguistic Theory 1, 1, 113-150. 
Uiboaed, Kristel, Kadri Muischnek, and Liina Lindström (2013) "Frequencies of verbs and verbal constructions across Estonian dialects and standard language". Presentation at an international workshop "The relative frequencies of nouns, pronouns, and verbs in discourse. An international workshop”, 13.08.2013, Leipzig.

Vare, Silvi (1991) “Kazuto Matsumura ettekandest Debreceni kongressil ning verbi ja verbaalnoomeni vahekorrast”. Keel ja Kirjandus 7, 408-415.

Viitso, Tiit-Rein (2008) Liivi keel ja läänemeresoome keelemaastikud. Tartu, Tallinn: Eesti Keele Sihtasutus.

Viitso, Tiit-Rein (2014) "Constructions of obligation, duty, and necessity in Livonian". Journal of Estonian and Finno-Ugric Linguistics 5, 1, 193-214.

Wiedemann, Ferdinand Johann (2011[1875]) Eesti keele grammatika. Edited by Ellen Niit. Translated by Heli Laanekask. Tallinn: Eesti Teaduste Akadeemia Emakeele Selts.

Yap, Foong Ha, Karen Grunow-Hårsta, and Janick Wrona, eds (2011) Nominalization in Asian languages: Diachronic and typological perspectives. (Typological Studies in Language, 96.) Amsterdam: John Benjamins.

Ylikoski, Jussi (2003) "Defining non-finites: action nominals, converbs and infinitives". SKY Journal of Linguistics 16, 185-237.

Kokkuvõte. Maarja-Liisa Pilvik: Deverbaalsed mine-teonimed eesti murrete korpuses. Artiklis kirjeldatakse eesti keele mine-teonimede tüüpilisi omadusi ja funktsioone, kasutades eesti murrete korpuse andmeid. Murdekorpus sisaldab mittestandardset kõneldud keelt, millel on ka geograafiline dimensioon, ning seetõttu on korpuse andmetel potentsiaal näidata mine-teonimede käitumises tegelikus keelekasutuses laiemat varieerumist. Seda ilmestab muuhulgas verbi argumentide mittekanooniline realiseerumine, nt patsienti väljendav lauseliige võib säilitada oma lauselise vormi nimisõnafraasides, mille peasõnaks mine-teonimi on. Artiklis puudutatakse ka probleeme, mis seonduvad regulaarselt tuletatavatele mine-teonimedele sõnaklassi määramisega, kui võtta arvesse kontekste ja konstruktsioone, milles mine-teonimed võivad esineda.

Võtmesõnad: murdesüntaks, teonimed, nominalisatsioon, konstruktsioonid, eesti keel 